\title{
Educational Biblical Nationalism and the Project of the Modern Secular State
}

\author{
Mette Buchardt \\ Aalborg University, Centre for Education Policy Research
}

\section{Abstract}

Biblical Criticism, the historical study of Biblical texts, spread across the European universities during the late $19^{\text {th }}$ century, the same period when the European states modernized, and identifying state and nation became a political project. The new scientific view on the Bible became in this political reform context a topic of public debate: Should the national education systems under construction implement the modern scientific understanding of the Bible, should school keep teaching the Catechism, or should religious instruction be separated from the school of the nation in order to become a 'school for all'?

Whereas the academic hotbeds of Biblical Criticism were not least the Germanspeaking universities and academic institutions in France, the popularization of Biblical Criticism through education proved more successful in the Nordic states than in e.g. Prussia and France. The article explores the gradual success of Biblical Criticism education reform efforts in the case of Denmark from the late $19^{\text {th }}$ to mid-20 $0^{\text {th }}$ century in relation to the development of the state from an absolutist kingdom to a nation state with constitutional monarchy and parliamentarism, and discusses on this basis the relation between religion, secularization and educational nation-state crafting.

Keywords: Biblical Criticism; Christian modernism; education reform; meso-level actors; nation-state crafting.

\section{Introduction}

The scientific study of religion, especially the Biblical scriptures, spread across the European universities during the late $19^{\text {th }}$ century. Biblical Criticism basically meant critical academic study and historization of Biblical texts, often overlapping with the new academic discipline History of Religion (later Comparative Religion). Both were 
part of the Liberal Theologian wave, and thus overlapping and being closely connected to modernist Christian intellectual movements such as Cultural Protestantism and Cultural Catholicism (Graf, 1990; Buchardt, 2013a; b; 2015; Weiss, 2014). Not least stemming from the German language universities, Biblical Criticism spread to other parts of Europe, e.g. France and the Nordic states, where it was also popularized and in different national forms intersected and became part of the political project of nation state crafting.

Based on a source material consisting of reform commission work, popular handbooks and pamphlets, writings in newspapers and magazines, and public lectures and debate in newspapers and periodicals, this article explores how Biblical Critical scholarship was disseminated and transformed in public enlightenment efforts and educational reforms in the case of Denmark along with the development of the state from an absolutist kingdom to a nation state with constitutional monarchy and parliamentarism from especially the 1890s to the 1930s. Which transformations of the relation between religion and state did Biblical Criticism influence, and which social and national imaginaries did it become part of (Taylor, 2007)?

Based on methodological considerations that establish what I conceptualize as Educational Biblical Nationalism within the research field of nationalism, religion and education, the paper will take its empirical point of departure in the rise of Biblical Criticism in the German-speaking university context in the $19^{\text {th }}$ century, and how Biblical Criticism subsequently spread and was more or less successfully sought popularized in education reform across Europe. The article then digs deeper into how Biblical Criticism was transformed into education in Denmark under inspiration from not least similar efforts in Sweden, and how it became a tool for and part of the development of a national and democratic imaginary through reform efforts targeting the education system. Subsequently, I discuss in what ways the case of Educational Biblical Nationalism in Denmark can contribute to our understanding of the relation between religion, secularization and educational nation-state crafting as it developed from the late $19^{\text {th }}$ century onwards.

\section{Methodological considerations: Educational Biblical Nationalism as a trans/national body of knowledge}

A number of studies have previously explored the relation between the Bible, especially the Old Testament (or the Hebrew Bible) and nationality and nationalism. Grosby (2002) argues that a premodern concept of nationality can be traced back to "the Ancient Israel", and Aberbach (2005) suggests that the Hebrew Bible has provided models of what he calls a secular national identity. Both works in different ways belong to the part of nationalism scholarship that argues for the nation as (also) a premodern phenomenon (Roshwald, 2019). Appelbaum (2013), on the other hand, finds signs of what she defines as Biblical Nationalism in post-reformatory Protestant $16^{\text {th }}$-century 
states in Europe that identified as "the new Israel". Though focusing on "the impact of the biblical model of nationhood", Appelbaum, however, refrains from subscribing to or opposing the thesis of a possible nationhood as form of governance in "ancient Israel" or "ancient Judea".

Picking up on the conceptualization of Biblical Nationalism, this paper is concerned with the use of the Bible in relation to modern national state crafting and as such in post-Enlightenment nationalism, taking up the question of how the Bible was used in crafting the education systems as part of modern nation-state crafting, such as raised by Tröhler (2020).

The methodological take will be to analyze the historical development of Biblical Critical scholarship in education as a development which is related to the process of nation-state crafting, but also that the history of the transformation of Biblical Critical scholarship was not only defined by this process. In addition, the process of nation-state crafting is to be understood as a complex and contextual phenomenon, of which e.g. the question of democracy, as in the Danish case, formed part. Finally, as the development in the chosen national case shows, transnational exchange was a central basis for nationalizing and educationalizing Biblical Criticism and thus to be interpreted as, rephrasing political historian Pauli Kettunen, a transnationally developed complex of knowledge that became the answer to nationally contextual questions (Kettunen, 2011) - in this case not least part of the national answer to "the national question".

The development of what I define as Educational Biblical Nationalism in the case of Denmark offers the possibility to discuss the magnitude of what Tröhler defines as national literacies in - with reference to Renan - "a constant process of being re-built" (Tröhler, 2020, p. 13), more specifically the role of religion under modernization and secularization in this context. The study of meso-level actors (Luft, 2020), actors operating "in the middle ground between high culture or science and ordinary life" (Rabinow, 1989, p. 9), will be at the fore. While I in my previous work on Nordic Cultural Protestantism and its influence on Nordic welfare-state crafting have already studied some of the male scholars in focus in this paper, work which I will revisit and reinterpret (e.g. Buchardt, 2013a; b; 2015; 2017), this paper will also include studies of female teacher educators and text book writers, who, as the paper argues, seem to be an overlooked reason for Biblical Criticism ending up becoming mainstream in the national comprehensive 'school for all' in the Danish context.

The methodological take in this paper will thus be to focus on the strategies of Biblical Critical scholars and teacher educators as the prism for studying the transformations of scholarly knowledge (produced at not least German universities) into a particular national education system aiming at a school for the whole population, in a way where I am rethinking the picture by means of agents who did not take the front stage or got the main media attention, etc., but rather belonged to the 'second row' of 
dissemination. Female teacher educators operating between scholarship and teachers training, textbook authorship and public debate are exactly to be understood as such.

\section{The dispersal of Biblical Criticism across European states and social fields}

A monument in the rise of Biblical Criticism was the publication of Biblical Critical scholar and Orientalist Julius Wellhausen's (1844-1918) Prolegomena zur Geschichte Israels (Prologue to the History of Israel) in 1882 in Berlin. In the introduction, Wellhausen defined "the problem" as the following: "The problem in this book is the historical status of the Mosaic law, and thus the concern is whether this can be the point of departure for a history of ancient Israel or for the history of Judaism, i.e. the religious community which survived the of the Assyrians and Chaldean eradicated "Volk' [people]" (Wellhausen, 1886/1882, p. 1).

Several implications were involved in those lines. First of all, Wellhausen's work imposed a new research hypothesis, namely that Deuteronomium, the five books of Moses or the Mosaic law in the "Old Testament" (or "the Hebrew Bible"), might be younger than previously assumed and thus instead of being a source to the history of the Kingdom of Israel was rather to be considered a source to a later period of time, meaning a source to the history of the religious community of Judaism. This scientific claim was grounded in the turn of the university theology towards modern science which had the ambition to make theology a modern and adequate scientific study of culture, with Orientalist philology and historical source criticism as the key methodological tools. This was connected to the development of new disciplines of culture, e.g. Orientalist studies and ethnography, closely connected to European colonialism, and with universities in the colonial powers of the German, the French and the British empires as its key centers. In the case of the German Empire - actually the incarnation after 1871 of the German nation state dreamed of by many since the beginning of the 19th century -, Biblical Criticism was launched in a context where political anti-Semitism was on the rise, which in turn inspired Zionism, which also understood the Jewish religion as a nation that deserved its own state like all other (European) nations (see article by Marva Sharev Marom in this issue). What was at stake in discussions around the historicity of the Old testament was in other words the geopolitical relation between Europe and "the Orient", the relation between Christianity and Judaism, and thus with the context of the German Empire the relation between the empire and the Jewish part of the population as more or less legitimate subjects to the empire (Graf, 1989; Sharpe, 1990; Heschel, 2005; Marchand, 2009).

Also the context for the scientific interest in Wellhausen's opening problem was the question of "Volk" and its relation to the state. The question of whether the Old Testament was a source for the history of a "Volk" as religious community or as kingdom was in this sense related to political, including academic investments in the question of "nation", a concept and political project which the historical sciences at 
the time increasingly invested in. "Volk" and "Nation" became overlapping concepts. The context of the book including its reception can thus not be understood outside the context of the national question, meaning the political reform processes that since the French revolution had increasingly become a political tool to connect the state with the idea of the nation as part of legitimizing and modernizing the state, a process that went along with negotiating the relation between the (nation) state and religion.

In 1906, when Wellhausen together with other key names in the partly crossconfessional Christian modernist movement published the volume Die christliche Religion, mit Einschluss der israelitisch-jüdischen Religion (The Christian religion, with inclusion of the Israelite-Jewish religion), the interest in "Volk" and its relation to political and/or religious entities was even more apparent. Among the authors of the volume were the Cultural Protestant church and dogma historian and Berliner professor Adolf Harnack (1851-1930) and Catholic church history professor in Tübingen Franz Xaver von Funk (1840-1907). The latter was a pioneer in historical and textual criticism who, besides theology, was also trained in classical philology and political economy, and who published a considerable part of his work in the "Historisches Jahrbuch der Görresgesellschaft", the yearbook of the Cultural Catholic Görresgesellschaft, a key environment of German language Catholic Modernism (Wellhausen, 1906; Kirsch, 1913; Weiss, 2014). Wellhausen opened his introduction by not only stating that "[d]ie Israelitisch-Jüdische Religion" was of huge importance for "der Kultur des Gegenwart" - the contemporary culture - as "Vorstufe" [pre-stage] to Christianity, but also that "Religion and 'Volk' from Israel belong together" (Wellhausen, 1906, p. 1).

Christianity was as such seen as interesting because it was defined as part of "the culture at present", and Judaism interesting as a pre-stage to this cultural development. In addition, the connection between religion and "Volk" was stipulated and connected to the political stately entity of Israel. A nexus between religion, "Volk", state and culture was in other words established and presumed in a way that pointed to and connoted the logic of political nationalism at the time. This scheme, significant for what was at the time often called "the new theology" and thus the Christian modernist project, spread with e.g. the dispersion of Biblical Criticism across Europe, just as the idea of the nation as identical with the state had spread across Europe since especially the early $19^{\text {th }}$ century.

In 1900, the Cultural Protestant theologian and historian of religion Edvard Lehmann (1862-1930) published a Danish version of Adolf Harnack's Das Wesen des Christentums (The Essence of Christianity), a series of lectures which became a landmark in the new critical historically based theology. It was the same year as the original German version came out, and as his collaborator Nathan Söderblom (1866-1931) published a Swedish edition in Stockholm (Harnack, 1904/1900). Both scholars were among the pioneers in the new discipline of the History of Religion, both intensively visited and worked at German universities, and both were involved in educational questions, e.g. the popularization of the Bible view of "the new theology" in school. 
In Lehmann's recontextualization, Harnack's understanding of historical studies as a central tool to reaching the goal of "endow[ing] Christianity with renewed growth and a new cultural legitimacy" was equated with the Biblical Criticism deriving from Old Testament professor Julius Wellhausen (Harnack, 1900b, pp. V, VIII). Historization was seen as a way to make Christianity relevant to the modern human being and 'the culture', and to turn Christianity into culture, for instance through schooling.

Other sources of inspiration in the Nordic context were French scholars such as the reformed Protestant Theologian, philosopher of religion and inspiration to the emerging study of Comparative Religion, professor in Strasbourg and later the Sorbonne and journalist Louis Auguste Sabatier (1839-1901), under whom Söderblom studied in Paris. Sabatier was a collaborator of a fellow liberal Protestant, the educationist Ferdinand Buisson (1841-1932), who, appointed by Minister of Education Jules Ferry (18321893), fronted the crafting of the laïcité acts. Being a Harnack-follower, he debated heavily with e.g. the more Harnack-skeptical Modernist Catholic philosopher, Biblical Criticism scholar and public promoter of Biblical Criticism Alfred Loisy (1857-1940) who after his excommunication from the Roman Church in 1908 became chair of the History of Religions at Collège de France.

Biblical Criticism was in other words a transnational and trans-confessional body of knowledge which nevertheless, when popularized, took national form after the questions that had been raised in the states in which the scholars worked and were based. The "new theology" did - namely - not only influence academia, but also spread to other fields of society outside the universities and the churches. This led to public debates about the status of the Bible and to the productions of new Bible histories that were purged of "irrationalities" such as miracles, aimed at reaching the modern human being, and at relating Bible history to the history of the nation.

The impact of the new science-based historical theology on political reform was very different across the European states. In the case of the Lutheran-dominated Nordic states Sweden and Denmark, this resulted in educational reform work and implementations, in the case of Sweden during the 1910s and in the case of Denmark during the 1930s, when religious education underwent a scientific and historical turn (Buchardt, 2013b; 2015; 2017). In Prussia, the cradle of Biblical Critical scholarship, the model of dual confessional religious instruction - Catholic and Protestant - and thus a more pluralist but also Catechist-based model seems to have worked against such a process (Rothgangel et al., 2016). In France, the Protestant scholars and promoters of the new theology did influence reform efforts leading up to the education acts of 1881 and 1882 under Minister of Education Jules Ferry, but here leading up to a separation of religion and the school (Mayer, 2004; Cabanel, 2016).

The impact and popularization of Biblical Criticism that later on to different degrees spread across Europe in other words seems to have its ideal typical case within the Nordic Lutheran states. While Sweden pioneered in the introduction of historical approaches to religious instruction in public schooling in 1919, a more gradual development and thus also more extensive example of discussions about the status of the Bible in the 
national education system under construction and reconstruction seems, however, to have been the case in Denmark.

Though slower and inspired by not least Swedish reform efforts, Denmark was the scene for several huge public education reform debates on the eventual implementation of the scientific view on the Bible in school from the 1890s to the 1930s. This process took place in a political environment of nation-state crafting and struggles about forms of democracy and suffrage, meaning the question of who belonged to the nation and to what degree. The process of connecting state and nation had its first important moment with the passing of the constitution in 1848 that broke with absolutist rule and meant a political success to e.g. the so-called national liberals. Following the defeat to Prussia in 1864, an increased national renaissance took place. This process was again connected to debates on forms of governing and the democracy or "folkestyre" [governance of the people], where parliamentarism was adopted in 1901, leading up to universal suffrage in 1915. All along with this, extensive reform efforts to create a comprehensive state education system took place.

\section{Biblical Criticism and the quest for national curricular reform in Denmark, 1890s-1920s}

Biblical Criticism had since the beginning of the 1890s been an object of struggle in Denmark. Orientalists and Old Testament scholars such as Frants Buhl (1850-1932), professor in Leipzig and later in Copenhagen who introduced Wellhausen's research in Denmark, had started debates about including the result of Biblical Criticism in the upper secondary school. This was met with protests from conservative church circles, revivalist movements and from teacher circles. Whereas the question of Darwinism was to some extent ignored by revivalist church groups, the question of the historical status of the Biblical scriptures became a main target for movements such as Inner Mission in the late $19^{\text {th }}$ century (Nørr, 1979; Hjermitslev, 2011, pp. 285286). Especially schooling became an arena for the "Bible storm", as head of the Zahle's Teachers College for Women Bertha Hahn (1848-1916) called it, which, as we shall see, did actually entangle with the question of the evolution theory. Hahn played a central, though largely overlooked role in the quest to not only disseminate the results of Biblical Criticism in Religious Education but also by further developing Biblical Critical scholarship. At N. Zahle's Teachers College for Women in Copenhagen, where Hahn was one of the leaders, scientific results from Biblical Criticism as well as the natural sciences were promoted.

Though the reform efforts were not successful on a policy level until the late 1930s, text books inspired by Biblical Criticism were published, for instance by Bertha Hahn who had studied under Buhl. ${ }^{1}$ In her Lille Bibelhistorie (Little Bible History, 1905) what seemed too irrational was removed: For instance the prophet Jonah simply "washed

\footnotetext{
${ }^{1}$ Jahn 1895 was translated into German and published in Dresden in 1908 (Jahn, 1908).
} 
up on the shore" rather than being swallowed and thus saved by a whale, as is the case in the Book of Jonah (e.g. Jahn [Pseudonym for Hahn], 1895; Hahn, 1904; 1905, p. 35). The task of educational Biblical Criticism was to remove the elements seen as scientifically irrational and replace them with a "rational history of development", as one of the churchly critics remarked (Poulsen, 1890, p. XV).

Understanding the Biblical history as the history of a people was from the outset a central endeavor, making it possible to relate it to the history of the Danish people. The latter was of increasing interest in these years following Denmark's defeat by Prussia in 1864. For Hahn, a Danish-speaking Southern Jutlander, 1864 entailed large personal costs, since the defeat forced her family to move. Also the change from absolutism into constitutive monarchy marked the late $19^{\text {th }}$ century. In 1901, parliamentarism was introduced, meaning that the political efforts to develop a comprehensive education system for the new modern state also gained momentum, and a reform that made it possible to access high school from all types of primary and secondary schools, meaning the public so-called Folkeskole [People's school], was adopted in 1902. This was undoubtedly an important move in creating a comprehensive education system allegedly accessible to the whole population from the bottom to the top of the educational ladder as well as with regard to social class, and thus also a tool for creating a national imaginary of democracy and "folkelighed". However, the 1902 reform changed neither the high school nor the Folkeskole curriculum with regard to implementation of the new scientific view on the Bible as history. Nevertheless, Biblical Criticism was dispersed and educationalized from the meso level. One of the institutions that already from the late $19^{\text {th }}$ century embraced the new scientific studies of the Bible were, as mentioned, the Zahle institutions, containing primary and secondary schools and teachers education colleges as well as courses for girls and women, founded by the educational reformer Nathalie Zahle (1827-1913). Under Hahn's influence, religious education grew from being a very small part of the Zahle curriculum into being a threefold subject matter containing Biblical Reading, History of Religion and Dogmatics. One of Hahn's arguments was according to her colleague and head Henriette Skram to make sure that the young girls and female teachers were not unprepared for the "Bible storm" which was to come, especially from "the camp of infidelity" (Skram, cit. Hilden, 1993, p. 85). Like other Liberal Theologian reformers, Hahn saw herself as the defender of Christianity against Atheists as well as against traditional church circles which the theologian liberals considered unable to reach the modern human being.

\section{Inspiration from the historicizing of religious instruction in Sweden, 1890s-1919}

Whereas a channel of dissemination was to be found in the female teacher education, the more successful efforts in Sweden were as mentioned above an important source of inspiration with regard to dissemination and transformation of Biblical Criticism into the national education system under construction. 
During the 1900s, Edvard Lehmann, also a part-time teacher at the Zahle institutions, Frants Buhl and Buhl's pupil Johannes Pedersen (1883-1977), scholar of semitic philology and the Old Testament, took up the Biblical Critical reform efforts, with the main goal to replace the Catechism with Biblical historical text readings in the school curriculum (Lehmann, 1906). This happened in exchange with and drawing on inspiration from reform efforts in Sweden, but their efforts did not prove successful in Denmark at the time with regard to legislation. ${ }^{2}$ The inspiration from Sweden seems to have been an important feature for the later development, not only with regard to the change of the status of the Catechism from an instruction book and into being of historical interest, but also with regard to ways of using "history" and "culture" as means to connect Christianity and thus "the Bible" into nation- and state interest, including connecting the latter two in practiced national and social imaginaries.

Since the beginning of the 1890s, a Cultural Protestant and Liberal Theologian milieu around the Stockholm-based publishing series I religiösa och kyrkliga frågor (In Religious and Ecclesiastical Matters) had developed, in which also Söderblom got involved. Key figures were the Stockholm-based pastor Frederik Fehr (1849-1895) and his follower, the Old Testament scholar Samuel S. Fries (1867-1914), both inspired by German Biblical Criticism. Fehr's reform ideas were to transfer the Cultural Protestant pledge for 'a new reformation' to a field where it could reach the modern cultural human being, namely the school. Christian ethics and history should be at the center of curriculum instead of the dogma which distanced modern man from Christianity (Söderblom, 1895; Skogar, 1999).

In 1919, religious education was subject to parliamentary reform, when Nathan Söderblom, at the time the Archbishop of Sweden, collaborated with the Social Democratic Minister of Education, the former teacher Värner Rydén (1878-1930), resulting in the abolition of the Catechism as the mandatory basis for instruction of religion. Moreover, a result was the introduction of the history of religion into the curriculum as the first country in the Nordic states (Moberger, 1961; 1962; Salqvist, 1947; Skogar, 1999). The Catechism remained part of the national curriculum, but now as a historical text among others, e.g. texts and persons from other religions, and texts from the Bible.

The role ascribed to history in this context deserves a closer look. In Söderblom's "Religionen och staten" (The religion and the state) (1918), a book targeting the public debate leading up to the 1919 reform, one of the main ideas was, in addition, that the future importance of Christianity was not as an institution and dogma, but as the culture and history of Sweden: "This living religious organism is so interwoven with Swedish culture [odlingen] and the history of the realm [rikets historia] that only ignorance or infatuation can see anything arbitrary in the fact that it and nothing else possesses a special relationship with the governance of the realm [rikstyrelsen] and by the state is used for religious and other tasks" (Söderblom, 1918, p. 5).

${ }^{2}$ Letters, Edvard Lehmann (KB-CPH); Letters to Nathan Söderblom from Edvard Lehmann (UUB). 
A new place for Christianity was not to be the exclusive religion of the state, but rather one with a special status as interwoven with Sweden and its culture, something which gave it a special role as performing a task for the state, not only of "religious" character. Christianity in this way was to be subordinated to the governance of the state and its interests, as part of the culture and history of the nation ["Sweden", "the realm"|"riket"]. The basic argument for this way of governing was in other words "history" "History" as a tool in religious instruction as well as in governing the relation between religion and the state in this sense relied on the connection between the state as government and the idea of Sweden as culture ["odlingen"] and history.

With regard to the question of nation and "people", this scheme became even more visible when Biblical Critical scholarship was directly included in central political reform in Denmark during the 1930s.

\section{Biblical Critical scholars attacked by Inner Mission proponents of Women's Rights, 1900s-1920s}

While Sweden passed a reform historicizing religious instruction, in Denmark not much happened with regard to government-related reform work until the 1930s. However, "the Bible storm" continued, and Biblical Criticism continued to spread in teacher education colleges across the country, through for instance Hahn's text books and through the Zahle-educated female teachers who became teacher educators elsewhere (Hilden, 1993).

Also from the opposite position, i.e. actors fighting against the scientific attacks on the Bible, female agents had an important voice, e.g. female teachers from the revivalist Pietist movements such as head of Inner Mission's teachers education college for women in Aarhus, Zahle-educated Astrid Blume (1872-1924), who publicly spoke up against the scientific attacks on the confessional basis of the school that was coming from Biblical Criticism and its proponents.

However, when it came to the question of women's rights and opportunities, a question that in the Danish context at the time was closely connected to the question of suffrage and thus to the question of "folkestyre" and democracy as part of nationstate crafting, it was a different story: Blume was a supporter of women's suffrage and publicly challenged what she considered the reactionary attitude towards women's rights to education among the theological liberals and proponents of Biblical Criticism. Conversely, female teachers from e.g. the Zahle institutions like Hahn were reluctant to publicly support women's suffrage.

In 1904-1905, Blume fought a battle against the efforts towards scientification of the religious education curriculum in the central pedagogical journal "Vor Ungdom" (Our youth). The counterpart in the debate was Villhelm Rasmussen (1869-1939), a teacher of Geography and Natural History. He became an MP for the Social Democracy in 1915 and head of Lærerhøjskolen - the Teacher In-service Training Institution from 1924, where he pursued his thesis that the education system should contribute to "class circulation" (Rasmussen, 1910). He was in other words not against class society, 
but as a declared Darwinist he was against the confessional religious education and thus he also embraced the critical study of the Biblical text or at least making the new theological results part of his argument. Blume for her part, educated in Religion as well as the natural sciences from the Zahle institutions, argued against Rasmussen that though it was evident that "[c]hildren should first and foremost learn what is empirically true [ ] the Christian knowledge for children [Børnelærdom] is something infinitely different from "free guessing"”, i.e. rather than to be understood as another kind of truth (Blume, 1905). Though fighting against what she considered reductionist atheism, Blume's counterarguments used a distinction between types of knowledge, and bore signs of the schooling into science and historization. Following the battle, Blume in 1909 became head of Inner Mission's newly established Female Teachers College for Women in Aarhus, founded not least to counteract the attacks on religious education in schools (Rimmen Nielsen, 1990, e.g. p. 185): Pious female teachers were needed in the struggle where the evolution theory and Biblical Criticism seemed to entangle when it came to the controversies over school curriculum and teaching. Several of them were however educated by the theologically liberal female teachers at the Zahle institutions.

Blume, an activist in the temperance movement, Outer Mission as well as in the women's movement, where she was a member of Dansk Kvindesamfund (Danish Women's Society), also clashed directly with leading figure of Danish Liberal Theology and proponent of Biblical Criticism Edvard Lehmann. Though not against women's suffrage, Lehmann's educational thoughts, disseminated in pedagogical publications, newspaper articles and public lectures, centered around how to maintain social difference in modern society and how to teach into a differentiated division of labor in a time when a national comprehensive education that, besides the sons from the "learned classes", included working-class and peasant children as well as women, enjoyed increasing political support. Women should, according to Lehmann, primarily be educated into labor in the domestic sphere, just as working-class and peasant children should be educated into manual labor within the national comprehensive school (Lehmann, 1910; 1914).

According to the memoirs of female teacher Hulda Pedersen, Blume outmaneuvered Lehmann publicly on the women's question (Pedersen, handwritten memoirs, pp. 123-125). Blume's position was that the tasks for women also included societal and social engagement, a direct consequence of the responsibility women should take on following their right to vote, a stance that was not uncommon among the Pious female teacher educationists related to Inner Mission (Rimmen Nielsen, 1990, pp. 184ff). The scientifically and theologically liberal Zahle teacher educators were mainly silent in the suffrage debate.

\section{Educational Biblical Nationalism in social democratic Denmark. Discussion and conclusion}

In Denmark, the reform work tried out by the Lehmann-Buhl circle did not gain parliamentary support until the Social Democracy came into office in the 1920s. In 
1933, a ground-breaking report, authored by a commission appointed by the Social Democrat Minister of Education Frederik Borgbjerg, suggested the replacement of a confessional basis of the school subject with so-called "objective teaching". The report became a central foundation of the later changes to the school subject that followed in 1937 and following the School Act of 1975, when the school subject - now called Kristendomskundskab (Knowledge about Christianity) - started to officially include "historical critical method", something that had increasingly been part of the teaching practice for several decades as can be seen from instruction books (Buchardt, 2016).

The commission's main architect of a new religious education was the Buhl pupil and Old Testament professor Aage Bentzen (1894-1953) (Bugge, 1968; 1979, pp. 61ff; Buchardt, [2006] 2011; 2013a; 2016). Though attacked by parts of the church, and embraced by anti-religious reform pedagogues, Bentzen's idea was not to remove Christianity as a resource in the state and its school. Rather, the Biblical gospel - set free by "objective science" - should be made accessible to the modern human being by means of understanding the Bible as a history of distinct nations and its respective peoples. The Old Testament should be treated as history "to become real to people", Bentzen argued (1933, p. 59). History as science was seen as a way to make "people" recognize themselves as a people, and hence the Bible history "should be written as a history of Denmark" (Bentzen, 1929, pp. 53, 56). Bentzen's arguments resembled in many senses previous arguments from Biblical Critical disseminators. However, the direct connection between scientific objectification of the Bible as a way to make "people" identify the history of "Israel" with the history of Denmark and thus contribute to the identification of 'Danes' as a people through Bible history in school was more concrete, elaborate and more literal than previous arguments (Bentzen, 1933, p. 12; Ibid., p. 10). This went hand in hand with Biblical Critical scholars now having access to the state body and influence on the design of curriculum policy. As in Sweden, it was the previously anti-religious Social Democrats that opened the door to popularization of Biblical Critical scholarship in the national education system. Educational Biblical Nationalism was thus also to be understood as a secularization model - a softer model than the radical division of church on the one hand and state and its school on the other. The nexus between Christianity and Bible (rather than church) and being a nation became a core element in this model.

To sum up, the Biblical Critical reform efforts of Cultural Christian modernist theologians in Denmark such as in the other Nordic state Sweden meant a transformation of Christianity from church institution into being understood as history and culture, and thus as a part of the national and social imaginary in the modern nation states under development. This was brought about in transnational exchange and cooperation and with Social Democrat state crafters as the gate openers. A central tool was "history as science" and Christianity and the Bible as "history of the people". Thus one might argue that scientification and re-sacralization seem to be intertwined in these efforts. What, in addition, the cases of Hahn and Blume and their institutions reveal is that 
female teacher education was an arena for dissemination of Biblical Criticism and thus liberalization of religion in the state institutions as well as a battlefield concerning it. Modernist Christian and Pietist Christian female teachers were the mid-level statecrafters and meso-level political actors in this context.

Thus, the case of educational Biblical Nationalism in Denmark shows how historization served as a national pedagogical tool when Biblical Criticism was turned into education. Also, studying the second-row actors on the meso level points to how the question of women in the project of national cohesion played a role as battlefield and motivation. The investment in the battles around scientificating and nationalizing the Bible for educational purposes, regardless of position, thus also interacted with nation-state crafting with regard to the form and definition of democracy.

The case of Denmark hence points to the fact that religion did not disappear from the nation-state project but was transformed into being a part of the new national and social imaginary where re-enchantment and re-sacralization of the state through a nexus of religion and folk/Volk and thus nation were central elements. Though research since the 1990s has challenged the presumed connection between the modern nationstate project and the project of secularization, Brubaker (2012) argues that it might still make sense to understand these projects as intertwined. The case at hand seems to support this view, but in a way which at the same time directs our attention toward how religion as a governing factor was rather transformed and maintained within the nation state than dissolved, and that this becomes not least apparent when studying the national comprehensive education system from the $19^{\text {th }}$ century onwards, as suggested by Tröhler (2020). The case of educational Biblical Nationalism in this context points to the fact that a secularized and re-sacralized body of nation-state knowledge became part of the national imaginaries of the Danish (and other Nordic) Protestant states. Rather than seeing this as a uniquely Lutheran and Social Democratic phenomenon, this calls for further explorations of different forms of possible educational Biblical Nationalism in states with other dominating forms of governing and other forms of confessional landscapes, and thus in other national versions of the project of the modern secular state.

\section{References}

\section{Unprinted sources}

Letters to Edvard Lehmann, The Royal Library, Copenhagen (KB-CPH).

Letters to Nathan Söderblom from Edvard Lehmann, Uppsala Universitetsbibliotek (UUB). Hulda Pedersen's papers, memoirs (handwritten), Kvindehistorisk Samling [Collection of Women's History], National Archive, Copenhagen.

Henriette Skram's papers, biographies, National Archive, Copenhagen. 


\section{Printed primary and secondary sources}

Aberbach, D. (2005). Nationalism and the Hebrew Bible, Nations and Nationalism, 11(2), 223-242. https://doi.org/10.1111/j.1354-5078.2005.00201.x

Appelbaum, D. M. (2013). Biblical nationalism and the sixteenth-century states. National Identities, 15(4), 317-322. https://doi.org/10.1080/14608944.2013.814624

Bentzen, A. (1933). Omkring Bibelhistorien [Regarding Bible History]. P. Haase \& Søns Forlag.

Bentzen, A. (1935). Bibelkritik og religionsundervisning [Biblical criticism and Religious Education]. Folkeskolen, July 4, 477-480.

Blume, A. (1905). Udviklingslæren og Folkeskolen - replikker [The Evolution Theory and The People's School]. Vor Ungdom, 194-195.

Brubaker, R. (2012). Religion and nationalism. Four Approaches. Nations and Nationalisms, 18(1), 2-20. https://doi.org/10.1111/j.1469-8129.2011.00486.x

Buchardt, M. (2017). Lutheranism and the Nordic States. In U. Puschner \& R. Faber (Eds.), Luther. Zeitgenössisch, historisch, kontrovers (pp. 285-295). Peter Lang. Zivilisation und Geschichte 50.

Buchardt, M. (2016). Historisk-kritisk undervisning [Historical Criticism instruction]. In M. Buchardt (Ed.), Religionsdidaktik: Traditioner og tilgange [Didactics of religion: Traditions and approaches] (pp. 119-137). Hans Reitzels Forlag.

Buchardt, M. (2015). Cultural Protestantism and Nordic Religious Education: An incision in the historical layers behind the Nordic welfare state model. Nordidactica, 2, 131-165.

Buchardt, M. (2013a). Pedagogical transformations of "religion" into "culture" in Danish state mass schooling from the 1900s to the 1930s. Paedagogica Historica: International Journal of the History of Education, 49, 126-138. https://doi.org/10.1080/00309230.2012.744068

Buchardt, M. (2013b). Religion, education and social cohesion: Transformed and traveling Lutheranism in the emerging Nordic welfare states 1890s-1930s. In M. Buchardt, P. Markkola, \& H. Valtonen (Eds.), Education, state and citizenship. A perspective in the Nordic Welfare State History (pp. 81-113). NordWel Studies in Historical Welfare State Research 4.

Buchardt, M. [2006] (2011). Forskerstriden om Det Gamle Testamente og de didaktiske konsekvenser [The scholarly struggles about the Old Testament and the didactical consequences]. In M. Buchardt (Ed.), Religionsdidaktik (pp. 232-245). Gyldendal.

Bugge, K. E. (1968). Striden Bentzen - Kaper 1933-34. En episode i dansk kristendomsundervisnings historie [The dispute Bentzen-Kaper 1933-34. An episode in the history of Danish Christianity Education]. Årbog for Dansk Skolehistorie (pp. 97-126). Selskabet for Dansk Skolehistorie.

Bugge, K. E. (1979). Vi har rel'gion. Et skolefags historie 1900-1975 [We have Religion. The History of a School Subject 1900-1975]. Nyt Nordisk Forlag Arnold Busck.

Cabanel, P. (2016). Ferdinand Buisson. Père de lécole Läique. Labor et Fides.

Graf, F.W. (1989). Rettung der Persönlichkeit. Protestantische Theologie als Kulturwissenschaft des Christentums. In R. von Bruch, F. W. Graf, \& G. Hübinger (Eds.), Kultur und Kulturwissenschaften um 1900. Krise der Moderne und Glaube an die Wissenschaft (pp. 103131). Franz Steiner Verlag Wiesbaden GmbH.

Graf, F. W. (1990). Kulturprotestantismus. In G. Müller (Ed.), Theologische Realenzyklopädie 20 (pp. 230-243). De Gruyter. 
Grane, L. (1980). Det teologiske Fakultet 1830-1925 [The Faculty of Theology 1830-1925]. In P. J. Jensen (Ed.), Københavns Universitet 1479-1979 5 (pp. 456-499). G E C Gads Forlag.

Grosby, S. (2002). Biblical ideas of nationality: Ancient and modern. Eisenbrauns.

Hahn, B. (1904). Bibelhistorie for Mellemskolen [Bible History for the Middle school]. Karl Schønbergs Forlag.

Hahn, B. (1905). Lille Bibelhistorie [Little Bible History]. Det Schønbergske Forlag.

Harnack, A. (1900a). Das Wesen des Christentums. J. C. Hinrichs.

Harnack, A. (1900b). Kristendommens Voesen [The Essence of Christianity]. V. Pios Boghandel.

Harnack, A. (1904/1900). Kristendomens väsen. Sexton populära föreläsningar hållna vid universitetet $i$ Berlin af Adolf Harnack; öfversätning af A. F. Åkersberg med ett förtal af professor Nathan Söderblom, andra upplagan [The Essence of Christianity. Sixteen popular lectures held at the university of Berlin by Adolf Harnack, translated by A. F. Åkersberg with a preface by Professor Nathan Söderblom, second edition]. Seligmanns förlag.

Heschel, S. (2005). Theology as a Vision for Colonialism. From Supersessionism to Dejudaization in German Protestantism. In E. Ames et al. (Eds.), Germany's Colonial Pasts. An Anthology in Memory of Susanne Zantop (pp. 148-163). University of Nebraska Press.

Hilden, A. (1993). Loererindeuddannelse, Dansk loereruddannelse 1791-1991 [Education of male Teachers. Danish Teacher Education 1791-1991], vol. III. Odense Universitetsforlag.

Hjermitslev, H. H. (2011). Protestant Responses to Darwinism in Denmark 1859-1914. Journal of the History of Ideas, 72(2), 279-303. https://doi.org/10.1353/jhi.2011.0010

Jahn, H. [Pseudonym for Bertha Hahn] (1895). Billeder fra det gamle Israel [Pictures from Ancient Israel]. Karls Schönbergs Forlag.

Jahn, H. [Pseudonym for Bertha Hahn] (1908). Bilder aus dem alten Israel. C. Ludwig Ungelenk.

Kettunen, P. (2011). The transnational construction of national challenges: the ambiguous Nordic model of welfare and competitiveness. In P. Kettunen \& K. Petersen (Eds.), Beyond Welfare State Models: Transnational Historical Perspectives on Social Policy (pp. 16-40). Edward Elgar.

Kirsch, J. P. (1913). Franz Xaver von Funk. Catholic Encyclopedia, 6. https://en.wikisource. org/wiki/Catholic Encyclopedia (1913)/Franz Xaver von Funk.

Lehmann, E. (1906). Om Bibelen at loese og loere [To Read and To Learn the Bible]. V. Pios Boghandel - T. Branner.

Lehmann, E. (1910). Opdragelse til Arbejde [Learning to labor]. V. Pios Boghandel - T. Branner.

Lehmann, E. (1914). Fremtidens Kvindesag [The Women's Question of the Future]. V. Pios Boghandel - Povl Branner.

Luft, A. (2020). Religion in Vichy France. How Meso-Level Actors Contribute to Authoritarian Legitimition. European Journal of Sociology, 61(1), 67-101. https://doi.org/10.1017/ $\underline{\text { S0003975620000041 }}$

Marchand, S. L. (2009). German Orientalism in the Age of Empire. Religion, Race, and Scholarship. Cambridge University Press.

Mayeur, F. (2004). Histoire Générale de L'Enseignement et de L'Éducation En France. De La Révolution à l'École républicaine (1789-1930). Perrin. 
Moberger, K. (1961). Religionsenhet och religionsfrihet i folkskolans kristendomsundervisning 1911-1919 I [Unity of Religion and Freedom of Religion in the Christianity Education of the Folk School I]. Kyrkohistorisk årsskrift, 154-225.

Moberger, K. (1962). Religionsenhet och religionsfrihet i folkskolans kristendomsundervisning 1911-1919 II [Unity of Religion and Freedom of Religion in the Christianity Education of the Folk School II]. Kyrkohistorisk årsskrift, 138-191.

Nielsen, H. R. (1990). Troende og dygtige loererinder. Loererindeuddannelse og -foellesskab på Århus (Kvinde)seminarium 1909-1950. En kvindekulturs rum og forestillinger [Pious and clever female teachers. Female teacher education and -community at Århus (Women's) Education College 1909-1950. Space and perceptions of a women's culture]. (Dissertation). Aarhus University.

Nørr, E. (1979). Det højere skolevoesen og kirken. Faget Religion i sidste halvdel af det 19. århundrede [The Higher School and the Church. The School Subject Religion in the Late 19th Century]. (Licentiate dissertation). Institut for Kristendomskundskab, Aarhus University, Akademisk Forlag.

Possing, B. (1992). Viljens styrke. Nathalie Zahle. En biografi [The Strength of the Will. Nathalie Zahle. A Biography], vol. I-II. Gyldendal.

Possing, B. (2003). Bertha Hahn. Dansk Kvindebiografisk Leksikon. http://www.kvinfo.dk.

Poulsen, A. S. (1890). Fra Kampen om Mosebøgerne [From the Battle over the Books of Moses/ The Pentateuch]. Gyldendalske Boghandels Forlag.

Rabinow, P. (1989). French Modern. Norms and Forms of the Social Environment. The University of Chicago Press.

Rasmussen, V. (1910). Samfunds-Skolen [School of Society]. Gyldendalske Boghandel Nordisk Forlag.

Roshwald, A. (2019). Nations are (Occasionally) Forever: Alternatives to the Modernist Perspective. In S. Berger \& E. Storm (Eds.), Writing the History of Nationalism (pp. 83103). Bloomsbury.

Rothgangel, M., Ziebertz, H.-G., \& Klutz, P. 2016. Religious Education at schools in Germany. In Rothgangel, M., M. Jäggle, \& T. Schlag (Eds.), Religious Education at schools in Europe, Part 1: Central Europe (pp. 115-148). Vandenhoeck \& Ruprecht. Wiener Forum für Theologie und Religionswissenschaft, Vienna University Press. https://doi.org/10.14220/9783737005135.115

Salqvist, B. (1947). Folkskolans kristendomsundervisning med särskild hänsyn till 1919 års undervisningsplan [Christianity Education of the Folk School with special regard to the 1919 curriculum]. (Prästmöteavhandling). Svenska Kyrkans Diakonistyrelses bokförlag.

Sharpe, E. (1990). Nathan Söderblom and the Study of Religion. The University of North Carolina Press.

Skogar, B. (1999). Kristendomsundervisningen under 1900-tallet. Några teologiska ansatser [Christianity Education during the 1900. Theological aspirations]. Pedagogisk Forskning i Sverige, 4, 305-326.

Söderblom, N. (1895). Frederik Fehr: Undervisning i kristendomen i anslutning till Luthers lilla Katekes [Fredrik Fehr: Teaching of Christianity in connection with Luther's Small Catechism]. Pedagogisk Tidsskrift, 3, 143-155. 
Söderblom, N. (1918). Religionen och staten [The Religion and the State]. P. A. Nordstedt \& Söners Förlag.

Taylor, C. (2007). A Secular Age. The Belknap Press of Harvard University Press.https://doi. org/10.2307/j.ctvxrpz54

Tröhler, D. (2020). National literacies, or modern education and the art of fabricating national minds. Journal of Curriculum Studies. https://doi.org/10.1080/00220272.2020.1786727

Tröhler, D. (2011). Languages of Education. Protestant Legacies, National Identities, and Global Aspirations. Routledge. https://doi.org/10.4324/9780203828427

Weiss, O. (2014). Kulturkatholizismus. Katholiken auf dem Weg in die deutsche Kultur 19001933. Verlag Friedrich Pustet.

Wellhausen, J. (1886/1882). Prolegomena zur Geschichte Israels [Prologue to the History of Israel), 3th edition. Georg Reimer.

Wellhausen, J. (Ed.) (1906). Die christliche Religion, mit Einschluss der israelitisch-jüdischen Religion. B.G. Teubner.

\section{Mette Buchardt}

Centre for Education Policy Research

Aalborg University

Kroghstræde 3, 3-205, 9220 Aalborg Ø, Denmark

buchardt@hum.aau.dk 


\section{Obrazovni biblijski nacionalizam i projekt moderne sekularne države}

\section{Sažetak}

Biblijski kriticizam, tj. povijesno proučavanje biblijskih tekstova, proširio se europskim sveučilištima tijekom kasnog 19. stoljeća, u istom periodu u kojem su se europske države modernizirale, a identifikacija države i nacije postala politički projekt. Neka znanstvena gledišta na Bibliju postala su tema javne rasprave u kontekstu spomenute političke reforme: trebaju li nacionalni obrazovni sustavi u okviru reforme primijeniti moderno znanstveno razumijevanje Biblije; treba li škola nastaviti poučavati katekizam ili bi se poduka religije trebala odvojiti od državne škole da bi postala škola za sve’?

Dok su akademska legla biblijskog kriticizma bila posebno sveučilišta na kojima se govorio njemački i akademske institucije u Francuskoj, popularizacija biblijskoga kriticizma kroz obrazovanje bila je uspješnija u nordijskim zemljama nego u npr. Prusiji i Francuskoj. U ovom radu istražuje se postupan uspjeh nastojanja reforme obrazovanja u području biblijskoga kriticizma u slučaju Danske iz perioda kasnog 19. do sredine 20. stoljeća, u odnosu na razvoj države iz apsolutističke kraljevine u nacionalnu državu s konstitucionalnom monarhijom i parlamentarizmom, i na toj osnovi propituje odnos izmedu religije, sekularizacije i obrazovnoga oblikovanja nacionalne države.

Ključne riječi: akteri srednje razine; biblijski kriticizam; kršćanski modernizam; oblikovanje nacionalne države; obrazovna reforma. 